\title{
CYTOTOXICITY OF LECTINS TOWARD SKIN FIBROBLASTS FROM PATIENTS WITH DUCHENNE MUSCULAR DYSTROPHY AND MYOTONIC DYSTROPHY
}

\author{
Kousaku OHno, Chizuko NaKano, Shougo IshII, and Kenzo TaKeshita \\ Division of Child Neurology, Institute of Neurological Sciences, \\ Tottori University School of Medicine, Nishi-machi 68, \\ Yonago 683, Japan
}

\begin{abstract}
Summary We analyzed the cytotoxicities of concanavalin A (Con A) and wheat germ aggulutinin (WGA) toward cultured skin fibroblasts from nine patients with Duchenne muscular dystrophy and four patients with myotonic dystrophy. The survival curves (relative colony-forming ability) of the patient fibroblast strains in the presence of either of the lectins were compared to those of seven normal male human fibroblast strains. The respective mean values for the inverse of the slope of the survival curve (D0) and the concentrations resulting in 10\% (D10) and $1 \%$ (D01) survival of each group were compared statistically. The nine Duchenne muscular dystrophy strains showed sensitivities to both Con A and WGA similar to those of the controls, except for the sensitivity to WGA in one strain. The sensitivity to Con A of the four myotonic dystrophy strains was almost the same as that of the controls. However, the survival curves in the presence of WGA suggested that the myotonic dystrophy fibroblasts have hypersensity to higher doses of WGA as compared with the controls.
\end{abstract}

\section{INTRODUCTION}

A number of lectins have been shown to bind to carbohydrates with high specificity. As most carbohydrates present on the cell surface are involved in many basic membrane-related functions such as cellular migration, recognition and adhesion, lectins are useful probes for investigating changes in membrane organization. Several lectins show cytotoxicity. Cytotoxic lectins can be used directly as selective agents to obtain resistant cell variants from many mammalian cell lines. The characterization of these lectin-resistant variants has already led to a tremendous increase in our understanding of biological roles and assembly of cell surface lectin receptors (for a review, see Briles, 1982). 
Some hereditary muscular dystrophies are believed to be due to defects of the surface of the cell membrane that are also manifested in other than muscle cells (Rowland, 1980; Jones and Witkowski, 1983). Altered carbohydrate compositions have been suggested in muscle cell or erythrocyte membranes from several muscular dystrophies by lectin cytochemistry or biochemical analysis (Bonilla et al,, 1978; Dunn et al., 1982; Paljarvi et al., 1984; Capaldi et al., 1984a; Stibler and Sydow, 1983, 1984). One approach to elucidating carbohydrate changes at the cell surface is to investigate whether the cytotoxic effects of lectins which recognize different carbohydrate moieties are different between dystrophic and normal cells. In this report, we described the cytotoxicities of concanavalin A (Con A) and wheat germ agglutinin (WGA) toward cultured skin fibroblasts from patients with Duchenne muscular dystrophy and myotonic dystrophy, and from apparently normal controls.

\section{MATERIALS AND METHODS}

Fibroblast cultures were established from skin biopsy specimens of the left upper arm in nine patients with Duchenne muscular dystrophy $(7.44 \pm 1.09$ years-old, aged 4 to 12$)$ and four patients with myotonic dystrophy $(10.5 \pm 1.25$ years-old, aged 7 to 14) who all belonged to the congenital type and were born to mother with this disease, and in seven apparently normal young males ( $7.43 \pm 1.14$, aged 4 to 14). Skin fibroblasts were grown in $5.1 \mathrm{~cm}$ Petri-dishes (Falcon) with $5 \mathrm{ml}$ of Dulbecco's modification of Eagle's medium with a glucose concentration of $1 \mathrm{~g} /$ liter (GIBCO, Berkeley, Calif.) and $500 \mathrm{IU} / \mathrm{ml}$ penicillin $\mathrm{G}, 100 \mu \mathrm{g} / \mathrm{ml}$ streptomycin sulfate and $10 \%$ fetal bovine serum (M.A. Bioproducts, Wilkersville, Maryland), as described previously (Ohno et al., 1984; Ohno and Takeshita, 1984). For cell transfer and for determination of the cell number with a Coulter counter (Model DN, Coulter Electronics Inc.), cells were dispersed in $0.05 \%$ trypsin in phosphate-buffered saline without calcium and magnesium, $\mathrm{pH} 7.4$, (PBS) containing $0.54 \mathrm{~mm}$ EDTA. All strains were negative for mycoplasma by fluorescent 33258 Hoechst staining (Chen, 1977).

Subconfluent cultures of each strain at population doubling levels between 7 and 15 (passage numbers between 4 and 8 ) were split at a ratio of $1: 8$. Two days later the medium was renewed. At three days after subculturing, cells proliferating actively were used for the experiments. To determine the colony-forming efficiency in the presence of various doses of lectins, actively proliferating cells were inoculated in $5 \mathrm{ml}$ of medium with $5 \%$ fetal bovine serum and $10 \%$ NU-SERUM (Collaborative Research Inc., Lexington, Mass.) at cell densities of 200 and 2,000 cells per $5.1 \mathrm{~cm}$ dish. At $24 \mathrm{hr}$ after cell seeding, various concentrations of lectins were added to the medium. The lectin from Canavalia ensiformis (Con A) was obtained from Sigma Chemical Co. (St. Louis, Missouri); the lectins from Triticum vulgaris (WGA) and Arachis hypogaea (PNA) were obtained from P-L Biochemical, Inc. (Milwaukee, Wis.). Stock solutions were dissolved in PBS (WGA, PNA) or in deionized and distilled water (Con A), and then sterilized by filtration. After two weeks, stained 
colonies of more than 50 cells were counted and relative colony-forming efficiencies were calculated. Quantitative data obtained from survival curves were D0, D10 and D01 values. The D0 (1/slope) of each curve was determined by least-square regression analysis of the data points of the exponential portion of the curve. The D10 and D01 values (doses reducing the colony-forming ability to $10 \%$ and $1 \%$, respectively) were determined by interpolation of the survival curves as to concentration.

\section{RESULTS}

The sensitivities of human skin fibroblasts to Con A and WGA were reproducible under our experimental conditions, and they were almost the same as that of Chinese hamster ovary cells, baby hamster kidney cells and mouse L cells (Wright, 1973; $\mathrm{Li}$ and Kornfeld, 1977). PNA was not toxic toward human skin fibroblasts even at a concentration of $300 \mu \mathrm{g} / \mathrm{ml}$, as in the case of mouse embryonal carcinoma cells (Draber and Stanley, 1984).

Survival curves for each strain in the presence of Con A and WGA are shown in Figs. 1 and 2. The shaded zone encompasses the survival curves of the seven

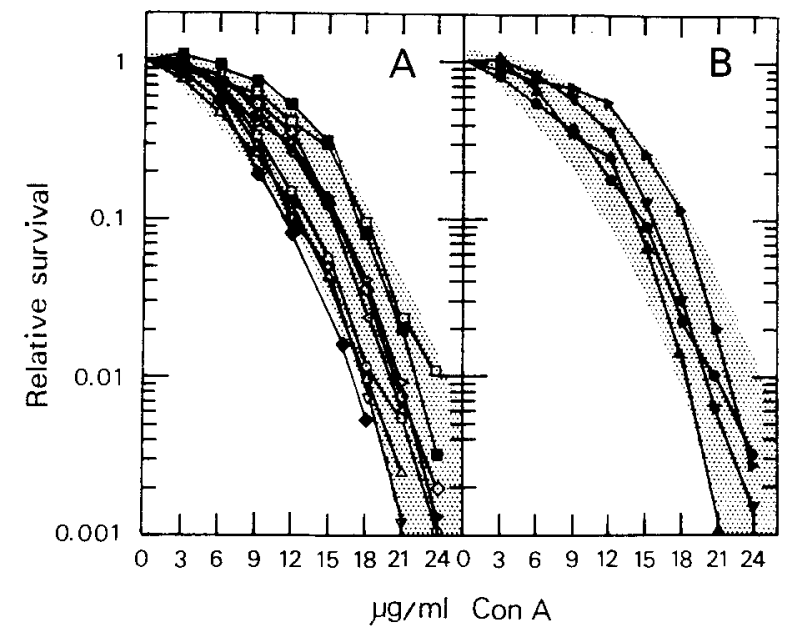

Fig. 1. Survival curves for Duchenne muscular dystrophy (A) and myotonic dystrophy fibroblasts (B) in the presence of concanavalin A. The shaded zone encompasses the survival curves of the 7 control strains. Each point represents the mean for at least triplicate plates inoculated at seeding cell densities of 200 cells and/or 2,000 cells per plate. The Duchenne muscular dystrophy strains are INS-D06 (12 years old) $(O)$, INS-D14 (12 years old) $(\triangle)$, INS-D07 (10 years old) $(\nabla)$, INS-D15 (10 years old) $(\triangleleft)$, INS-D12 (5 years old) ( () ), INS-D20 (5 years old) ( $\square$ ), INS-D22 (5 years old) $(\diamond)$, INS-D13 (4 years old) $(\boldsymbol{\square})$, and INS-D24 (4 years old) $(\diamond)$. The myotonic dystrophy strains are INS-D10 (14 years old, male) (๑), INS-D11 (11 years old, male) (A), INS-D04 (10 years old, female) ( $\boldsymbol{\nabla})$, and INS-D17 (7 years old, female) ( $\rightarrow$ ). 


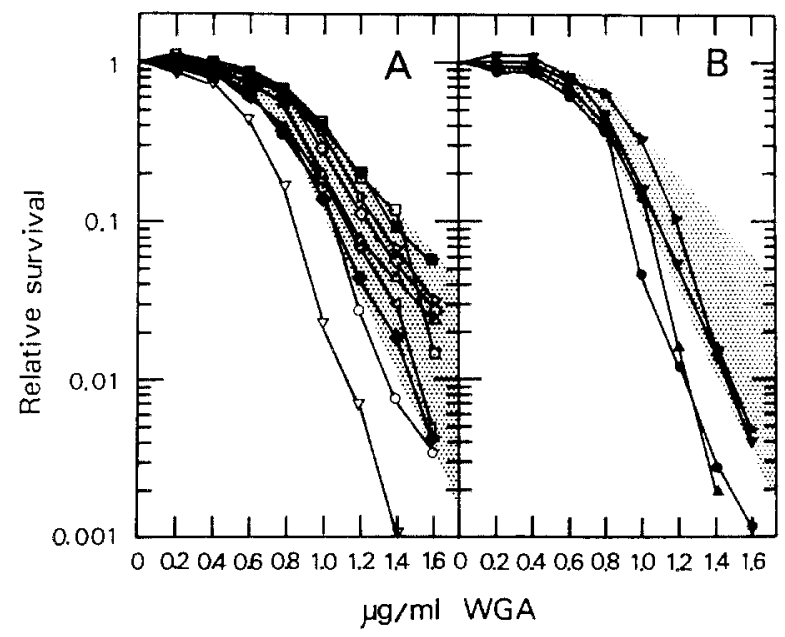

Fig. 2. Survival curves for Duchenne muscular dystrophy (A) and myotonic dystrophy fibroblasts (B) in the presence of wheat germ agglutinin (WGA). The shaded zone encompasses the survival curves of the 7 control fibroblasts. Each point represents the mean for at least triplicate plates inoculated at seeding cell densities of 200 cells and/or 2,000 cells per plate. The symbols are the same as in Fig. 1.

Table 1. Summary of survival parameters of fibroblasts from patients with Duchenne muscular dystrophy, myotonic dystrophy and controls in the presence of concanavalin A or wheat germ agglutionin. The values are means \pm SEM.

\begin{tabular}{lccccccc}
\hline & \multicolumn{3}{c}{ Concanavalin A $(\mu \mathrm{g} / \mathrm{ml})$} & & \multicolumn{3}{c}{ Wheat germ agglutinin $(\mu \mathrm{g} / \mathrm{ml})$} \\
\cline { 2 - 3 } & D0 & D10 & D01 & & D0 & D10 & D01 \\
\hline $\begin{array}{l}\text { Controls }(\mathrm{n}=7) \\
\begin{array}{c}\text { Duchenne muscular } \\
\text { dystrophy }(\mathrm{n}=9)\end{array}\end{array}$ & $2.68 \pm 0.15$ & $14.8 \pm 0.72$ & $20.4 \pm 0.64$ & & $0.28 \pm 0.03$ & $1.24 \pm 0.06$ & $1.85 \pm 0.13$ \\
$\begin{array}{c}\text { Myotonic dystrophy } \\
(\mathrm{n}=4)\end{array}$ & $2.32 \pm 0.28$ & $15.1 \pm 0.72$ & $20.1 \pm 0.78$ & & $0.16 \pm 0.02^{\mathrm{a}}$ & $1.06 \pm 0.05$ & $1.39 \pm 0.06^{\mathrm{a}}$ \\
\hline
\end{tabular}

a $0.01<\mathrm{p}<0.05$.

normal controls. No differences in the sensitivity to Con A between the controls and the muscular dystrophy strains were found. In the case of WGA (Fig. 2), cells from Duchenne muscular dystrophy patients showed similar sensitivities to controls, except for one strain, INS-D7, from a 10 years-old patient (Fig. 2A), whereas the survival curves for the four myotonic dystrophy patients extended from the lower part of the normal zone to well below that zone in the presence of higher concentrations of WGA (Fig. 2B). The mean D0, D10 and D01 values for these four myotonic dystrophy patients were $0.16,1.06$ and 1.39 , respectively (Table 1), that is, significantly less $(p<0.05)$ than the corresponding mean values of each of the seven 
normal strains with the exception of the D10 value which was not significantly less than that of the normal strains $(0.05<\mathrm{p}<0.1)$.

\section{DISCUSSION}

Binding abnormalities of Con A, WGA, PNA and Ricinus communis I (RCA I) to biopsied muscle from patients with Duchenne muscular dystrophy have been reported (Bonilla et al., 1978; Dunn et al., 1982; Paljarvi et al., 1984; Capaldi et al., 1984a). However, Con A, WGA and PNA binding abnormalities reported in biopsied muscle are suggested to be related to increased connective tissue in dystrophic muscle (Dunn et al., 1982). Certainly, cultured muscle cells (Heiman-Patterson et al., 1982) and skin fibroblasts (Newman, 1982; Hellmann et al., 1984) bind normally with Con A. With respect to RCA I, reduced binding is suggested to be common to several muscular dystrophies, including Duchenne muscular dystrophy (Capaldi et al., 1984b). Our study also failed to provide evidence for significant alterations in Con A and WGA sensitivities of fibroblasts from patients with Duchenne muscular dystrophy, except for that to WGA in one strain. These findings suggest that the abnormal lectin binding in muscle tissues from Duchenne muscular dystrophy is not due to a basic cellular abnormality caused by the mutation, which presumably expressed in the cell membrane of various tissues (Rowland, 1980; Jones and Witkowski, 1983), but merely reflects an effect of increased connective tissues in dystrophic muscle. The reason why one strain is more sensitive to WGA than the strains from the other Duchenne muscular dystrophy patients and the controls is unknown.

In this investigation we demonstrated that strains from four patients with myotonic dystrophy showed hypersensitivity to WGA, by comparing the mean D0 and D01 values for myotonic dystrophy fibroblasts to those for seven control strains. Because of the small difference in the sensitivity to WGA and somewhat higher mean age in myotonic dystrophy patients as compared with controls (though the difference in the mean age is not significant), the interpretation of the result requires circumspection. An attempt to relate these alterations to the carbohydrate change of the cell membrane that occurs in myotonic dystrophy (Stilber and Sydow, 1983, 1984) is interesting. Among a number of distinctly different lectin-resistant mammalian mutations, WGA resistancy is closely related to membrane sialic acid deficiency (Briles, 1982). In myotonic dystrophy, a carbohydrate deficiency of the erythrocyte membrane, which is restricted to sialic acid, has been described (Stibler and Sydow, 1983). A possible relationship between the hypersensitivity to WGA and the alterations in sialic acid composition is of particular interest. It is also possible that the toxic effects of WGA are strengthened by presumed plasma membrane dysfunctions in myotonic dystrophy, such as calcium (Plishker et al., 1978) or glucose transport (Malby et al., 1981), ATPase activity (Johnsson et al., 1983) and insulin-binding affinity (Moxley et al., 1981; Lam et al., 1983). Because WGA is known to affect 
certain functions of membranes such as multiple transport systems (Isselbacher, 1972; Greene et al., 1976; Li and Kornfeld, 1977).

Acknowledgment This study was supported in part by Grant Nos. 57770549 and 59770550 (to K.O.) from the Ministry of Education, Science and Culture of Japan.

\section{REFERENCES}

Bonilla, E., Schotland, D.L., and Wakayama, Y. 1978. Duchenne muscular dystrophy-Focal alterations in the distribution of concanavalin A binding sites at the muscle cell surface. Ann. Neurol. 4: 117-123.

Briles, E.B. 1982. Lectin-resistant cell surface variants of eukaryotic cells. Int. Rev. Cytol. 75: 101-165.

Capaldi, M.J., Dunn, M.J., Sewry, C.A., and Dubowitz, V. 1984a. Altered binding of Ricinus communis I lectin by muscle membranes in Duchenne muscular dystrophy. J. Neurol. Sci.63: 129-142.

Capaldi, M.J., Dunn, M.J., Sewry, C.A., and Dubowitz, V. 1984b. Binding of Ricinus communis I lectin to the muscle cell plasma membrane in diseased muscle. J. Neurol. Sci. 64: 315-324.

Chen, T.R. 1977. In situ detection of mycoplasma contamination in cell cultures by fluorescent Hoechst 33258 stain. Exp. Cell Res. 104: 255-262.

Draber, P. and Stanley, S. 1984. Cytotoxity of plant lectins for mouse embryonal carcinoma cells. Somat. Cell Mol. Genet. 10: 435-443.

Dunn, M.J., Sewry, C.A., and Dobowitz, V. 1982. Cytochemical studies of lectin binding by diseased human muscle. J. Neurol. Sci. 55: 147-159.

Greene, W.C., Parker, C.M., and Parker, C.W. 1976. Opposing effects of mitogenic and nonmitogenic lectins on lymphocyte activation. J. Biol. Chem. 251: 4017-4025.

Heiman-Patterson, T.D., Bonilla, E., and Schotland, D.L. 1982. Concanavalin A binding of the cell surface of Duchenne muscle in vitro. Ann Neurol. 12: 305-307.

Hellman, H., Jamieson, J.C., Parfett, C.L.J., and Wright, J.A. 1984. Concanavalin A binding to fibroblasts from Duchenne muscular dystrophy patients and age-matched controls. J. Neurol. Sci. 65: 315-321.

Isselbacher, K.J. 1972. Increased uptake of aminoacids and 2-deoxy-D-glucose by virus-transformed cells in culture. Proc. Natl. Acad. Sci. U.S.A. 69: 585-589.

Johnsson, R., Somer, H., Karli, P., and Saris, N.E. 1983. Erythrocyte flexibility, ATPase activities and $\mathrm{Ca}$ effux in patients with Duchenne muscular dystrophy, myotonic muscular dystrophy and congenital myotonia. J. Neurol. Sci. 58: 399-407.

Jones, G.E. and Witkowski, J.A. 1983. Membrane abnormalities in Duchenne muscular dystrophy. J. Neurol. Sci. 58: 159-174.

Lam, L., Hudson, A.J., Strickland, K.P., and Tevaarwerk, G.J.M. 1983. Insulin binding to myotonic dystrophy fibroblasts. J. Neurol. Sci. 58: $289-295$.

Li, E. and Kornfeld, S. 1977. Effects of wheat germ agglutinin on membrane transport. Biochim. Biophys. Acta 469: 202-210.

Malby, E., Strickland, K.P., Tevaarwerk, G.J.M., and Hudson, A.J. 1981. Glucose transport and oxidation in adipose tissue of patients with myotonic dystrophy. J. Neurol. Sci. 52: 11-23.

Moxley, R.T., III, Livingston, J.N., Lockwood, D.H., Griggs, R.C., and Hill, R.L. 1981. Abnormal regulation of monocyte insulin binding affinity after glucose ingestion in patients with myotonic dystrophy. Proc. Natl. Acad. Sci. U.S.A. 78: 2567-2571.

Newman, G.C. 1982. Duchenne muscular dystrophy cultured skin fibroblasts stain normally with concanavalin A. J. Neurol. Sci. 54: 353-358. 
Ohno, K., Okuda, A., Ohtsu, M., and Kimura, G. 1984. Genetic analysis of control of proliferation in fibroblastic cells in culture. I. Isolation and characterization of mutants temperaturesensitive for proliferation or survival of untransformed diploid rat cell line $3 \mathrm{Y} 1$. Somat Cell Mol. Genet. 10: 17-28.

Ohno, K. and Takeshita, K. 1984. Patients with tuberous sclerosis have fibroblasts with normal limits for growth characteristics and sensitivities to DNA alkylating agents. Jpn. J. Human Genet. 29: 359-369.

Paljarvi, L., Karjalainen, K., and Kalimo, H. 1984. Altered muscle saccharide pattern in X-linked muscular dystrophy. Arch. Neurol. 41: 39-42.

Plishker, G.A., Gitelman, H.J., and Appel, S.H. 1978. Myotonic muscular dystrophy-Altered calcium transport in erythrocytes. Science 200: 323-325.

Rowland, L.P. 1980. Biochemistry of muscle membranes in Duchenne muscular dystrophy. Muscle Nerve 3: 3-20.

Stibler, H. and Sydow, O. 1983. The sialic acid and galactose concentrations in erythrocyte membranes in patients with myotonic dystrophy, limb-girdle and facioscapulohumeral dystrophy. J. Neurol. Sci. 59: 389-399.

Stibler, H. and Sydow, O. 1984. Carbohydrate composition of erythrocyte membranes and glycosidase activity in serum in patients with myotonic dystrophy, limb-girdle dystrophy and congenital myotonia. J. Neurol. Sci. 63: 285-298.

Wright, J.A. 1973. Evidence for pleiotropic changes in lines of Chinese hamster ovary cells resistant to concanavalin A and phytohemagglutinin. J. Cell Biol. 56: 666-675. 